\title{
Membongkar Konsep “Heroisme’ di Film Gundala
}

\author{
Oleh : \\ Teguh Hidayatul Rachmad \\ Program Studi Ilmu Komunikasi, Fakultas Ilmu Sosial dan Humaniora, Universitas Bunda \\ Mulia \\ E-mail: trachmad@bundamulia.ac.id
}

\begin{abstract}
Abstrak
Kemunculan film gundala memberikan arti tersendiri bagi bangsa Indonesia akan kehadiran film yang mengangkat tema pahlawan Indonesia yaitu Gundala. Pahlawan Lokal yang menjadi budaya Indonesia masih belum diangkat dalam jagad raya perfilman di Indonesia. Hal ini menjadi peluang bagi bisnis perfilman Indonesia, mengingat kesuksesan dari film internasional yang berjudul "The Avengers". Momen ini yang menjadi fokus penelitian yang berjudul "Membongkar Konsep "Heroisme' di Film Gundala" yang akan dikorelasikan dengan pendekatan ekonomi politik media dengan paradigma kritis. Hal yang menarik dari penelitian ini adalah membuka produksi makna dalam relasi kekuasaan yang ada di film Gundala. Hasil penelitian ini akan mengetahui dengan jelas relasi kekuasaan yang ada di film gundala, sehingga masyarakat akan lebih reflektif dan kritis untuk memahami dan mempelajari suatu fenomena dalam realitas sosial di masyarakat.
\end{abstract}

Kata Kunci: Film Heroisme, Gundala, Ekonomi Politik Media

\section{PENDAHULUAN}

Perfilman yang ada di Indonesia terbilang pertumbuhan dan perkembangannya cukup pesat serta sangat beragam genre atau alirannya. Masyarakat Indonesia tinggal memilih secara aktif kesenangan menonton film sesuai dengan keinginan dan hobinya. Menonton film menjadi keharusan yang mutlak dalam masyarakat urban untuk relaksasi dari aktivitas pekerjaan atau biasa disebut oleh McQuail, Blumler, Brown (1972) sebagai escaping, or being diverted, from problems. Individu dalam masyarakat di era teknologi sekarang sangat membutuhkan informasi sebagai kebutuhan primer agar up to date, bukan lagi tersier. Film yang ditonton oleh masyarakat, khususnya di Indonesia menggunakan media visual yang menekankan kepada indera penglihatan dan suara, diantaranya ; televisi, bioskop dan handphone atau laptop.

Penayangan film yang menggunakan media televisi, bioskop, handphone atau laptop mempunyai target market yang berbeda-beda, hal ini dikarenakan oleh karakter dari media itu sendiri. Masyarakat yang menonton di televisi memiliki perilaku yang cukup unik dan beragam. Sesuai dengan teori kultivasi bahwa masyarakat yang menonton televisi terbagi menjadi dua kelompok, yaitu : para penonton fanatik (heavy viewers)/the television type adalah yang menonton televisi lebih dari empat jam setiap harinya, sedangkan tipe penonton yang kedua adalah penonton biasa (light viewers) yang menonton televisi 2 jam atau kurang dalam setiap harinya. Dalam studi nielsen tentang pola konsumsi media pada masyarakat Indonesia menjelaskan bahwa 5 jam waktu yang dihabiskan untuk menonton 
televisi (www.nielsen.com), sehingga sangat jelas sekali bahwa masyarakat Indonesia tergolong dalam kategori the television type atau masyarakat yang kecanduan akan program tayangan televisi yang salah satunya adalah film, seperti yang terlihat dalam infografis yang ada di bawah ini dengan pembagian media menjadi 5 jenis, yaitu televisi, radio, koran, majalah, dan internet :

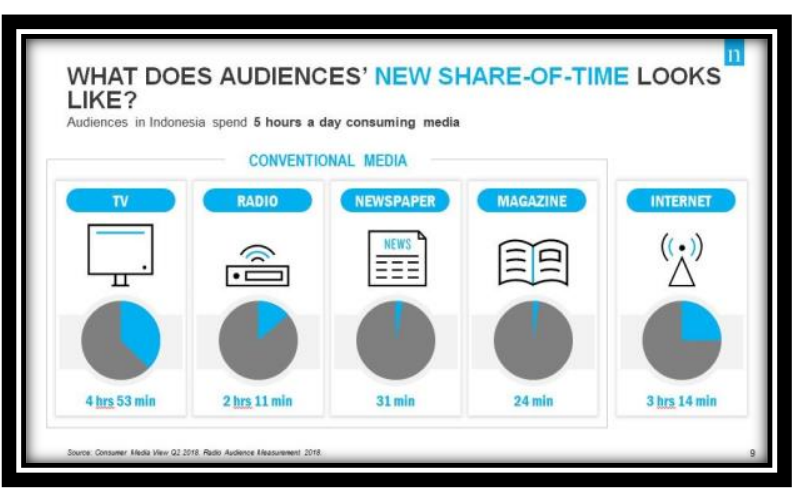

Infografis I.1

Survey Penonton Media Konvensional

Kegemaran masyarakat untuk menonton film menjadi sebuah budaya massa yang berakibat dalam tingkah laku dalam sehari-hari. Kegiatan menonton film tidak hanya dilakukan di rumah atau tempat tinggal melalui televisi, tetapi juga bisa di ruang publik melalui smartphone secara individu. Menonton film di ruang publik secara massa bisa dinikmati di dalam bioskop yang telah disediakan di pusat perbelanjaan atau mall.

Jumlah penonton bioskop sebagian besar dari kalangan kelas menengah dan kelas atas. Hal ini dikarenakan syarat untuk masuk ke bioskop harus berbayar. Namun, hal tersebut tidak membuat bioskop menjadi sepi peminatnya. Semua film yang ditayangkan di bioskop menjadi magnet masyarakat untuk menonton program tayangan yang belum ada di televisi. Banyak sutradara, aktor, produser, aktris dan crew pembuatan film yang berjaya dan sukses di industri film layar lebar. Ini adalah bukti bahwa pertumbuhan film dan penggemar bioskop berjalan efektif dan saling mendukung satu sama lain. Kemunculan film dalam negeri menambah suasana kompetitif dengan luar negeri semakin tinggi yang berdampak sebanding dengan pertumbuhan iklan-iklan komersial di film bioskop.

Dinamika industrialisasi film di bioskop semakin meningkat dan bersaing antara perusahaan pengiklan, production house, pemerintah, dan beberapa instansi lainnya. Persaingan yang ada di dunia industri perfilman tidak terlepas dari unsur kapitalisme. Pemilik modal melihat ceruk pasar yang potensial di dunia perfilman dan harus mencari keuntungan yang sebesarbesarnya. Perspektif Film dalam budaya kapitalisme menjadi bisnis media. Fungsi film bukan hanya sebagai karya seni, namun juga representasi budaya dari suatu etnis, negara, dan organisasi kelompok lainnya.

Berbagai genre film menjadi komoditas utama untuk mencari pasar yang potensial agar film tersebut tetap bertahan di bioskop-bioskop yang ada di Indonesia. Jaringan bioskop membuat film menjadi tumbuh subur di Indonesia, diantaranya ada lima branding bioskop yang sudah terkenal dan banyak terdapat di mal atau pusat perbelanjaan yaitu : Cineplex 21 group, CGV, Cinemaxx, Platinum Cineplex, dan New Star Cineplex. Peningkatan fasilitas 
mulai dari sarana dan prasarana membuat penonton bioskop menjadi semakin nyaman dan suka untuk menonton film diantara lima bioskop. Persaingan diantara founder bioskop memperluas target market dan user pecinta film.

Salah satu genre yang menjadi pusat perhatian di tahun 2019 adalah heroisme dengan aktor dan aktris dari Indonesia. Tokoh yang diperankan berasal dari legenda dan cerita rakyat dari bangsa Indonesia. Beberapa contoh super hero Indonesia yang merupakan hasil konstruksi masyarakat dari cerita rakyat, dongeng, mitos, dan legenda adalah Si Buta Dari Goa Hantu, Gundala, Si Pitung, Nyi Roro Kidul, Sarip Tambakoso dan masih banyak lagi. Hasil pemikiran super hero khas Indonesia yang dibuat dalam bentuk layar lebar di bioskop, untuk yang pertama kali yaitu Gundala diproduksi oleh Bumilangit Studios yang bekerjasama dengan Screenplay Films dan Legacy Pictures.

Gundala merupakan film pahlawan super lokal yang mengangkat cerita pahlawan super Indonesia tahun 1969, Gundala Putra Petir, yang karakternya dibuat Harya Suraminata atau Hasmi. Dalam film, tokoh Gundala diperankan oleh Abimana Aryasatya (https://seleb.tempo.co). Pembuatan karakter Gundala dikonstruksi oleh Joko Anwar sekaligus sutradara dari film gundala "negeri ini butuh patriot". Motivasi dari sutradara Joko Anwar untuk membuat film gundala hasil dari imajinasi Hasmi yang dituangkan dalam cerita bergambar (19691971), komik (1971-1982), Film (1981) yang kemudian dibuat kembali di tahun 2019 dengan perubahan dari kostum dan setting film Gundala.

Tema besar dari film Gundala yang di launching tanggal 29 Agustus 2019 yang secara tidak langsung bertepatan dengan hari kemerdekan Republik Indonesia menjadi momentum yang tepat sesuai dengan tema Gundala "negeri ini butuh patriot". Tema film heroisme dari Gundala menjadi kebutuhan yang sangat diprioritaskan, sama halnya dengan menemukan air di padang pasir. Beberapa film yang menjadi trending topic dan dikerjakan oleh sutradara terkenal selalu yang bertemakan tentang cinta, horror, drama, dan action. Kemunculan tema heroisme dalam dunia per-film-an di Indonesia masih belum ada dan dipelopori pertama kali oleh film Gundala. Joko Anwar dan bumi langit studio terinspirasi genre film heroisme dari negara-negara barat yang notabene-nya sebagai Negara adikuasa.

Film heroisme hanya diproduksi oleh negara barat yang sebagian besar adalah negara maju dengan dua produsen perusahaan besar yaitu Detective Comics (DC) dan Marvel Comics. Pembuatan karakter dalam komik DC dan Marvel yang kemudian dijadikan film merupakan satu terobosan besar dalam dunia perfilman yang mengakibatkan animo masyarakat dalam menikmati keseruan menonton bioskop menjadi bertambah. Akhirnya, genre film heroisme menjadi salah satu pilihan dari masyarakat global untuk menikmati dan menonton film di bioskop. Pertumbuhan dan perkembangan film menjadi sangat menarik 
diteliti karena adanya kesamaan genre film dalam ruang dan waktu yang berbeda. Globalisasi tidak menjadi hambatan untuk menciptakan networking dalam konteks dunia perfilman.

Penelitian tentang genre film dilihat dari frame ekonomi politik media masih sangat minim. Sama halnya dengan studi ekonomi politik media yang dikorelasikan dengan perkembangan serta pertumbuhan film masih jarang ditemukan. Aspek novelty tersebut yang membuat peneliti ingin melakukan riset yang berjudul "Membongkar Konsep Heroisme di Film Gundala"

\section{Urgensi Penelitian}

Khazanah keilmuan dalam dunia ilmu komunikasi seharusnya tidak dibatasi oleh dogma-dogma keilmuan itu sendiri. Pembatasan teori dalam konseptualisasi objek penelitian menghadirkan homogenisasi hasil penelitian. Akibatnya tidak adanya perkemabangan teori dalam dunia komunikasi itu sendiri. Studi ekonomi politik media hanya terdapat dalam program tayangan di televisi, selain itu masih jarang digunakan dalam objek penelitian selain televisi.

Penelitian ini mencoba untuk mengembangkan teori ekonomi politik media dalam frame yang lebih luas lagi, tidak hanya di dunia televisi, namun dalam hal per-film-an. Apakah teori ekonomi politik media masih relevan untuk digunakan dalam membongkar film gundala?. Hal inilah yang akan menjadi warna dinamika teori dan konsep penelitian yang terbarukan.

Kemunculan film Gundala di bulan Agustus tidak datang begitu saja, namun pasti ada suatu makna, kepentingan dan keuntungan yang didapat dalam produksi film tersebut. Kemiripan film Gundala dengan film-film super hero di Negara barat adakah hubungannya atau tidak?

Tidak hanya menggunakan satu teori (ekonomi politik media) saja, namun ada beberapa teori yang digunakan oleh peneliti untuk mengupas dan membongkar genre film heroisme yang terbilang baru di jagad raya per-film-an Indonesia. Gundala adalah satu film yang sangat penting untuk dijadikan objek penelitian dikarenakan kisahnya diangkat dari komik di era tahun 1969 an. Perubahan konteks dan konten Gundala dari tahun 1969 ke 2019 menjadi satu hal yang unik untuk diteliti karena ada dua hipotesa apakah film tersebut masih sama atau sudah berubah isinya?

\section{Rumusan Masalah}

Berdasarkan uraian latar belakang masalah sertai deskripsi identifikasi masalah, maka rumusan masalah dalam penelitian ini adalah sebagai berikut:

1. Melihat studi ekonomi politik media dalam membongkar genre heroisme di film Gundala

\section{TINJAUAN TEORITIS}

\subsection{Kerangka Pemikiran}




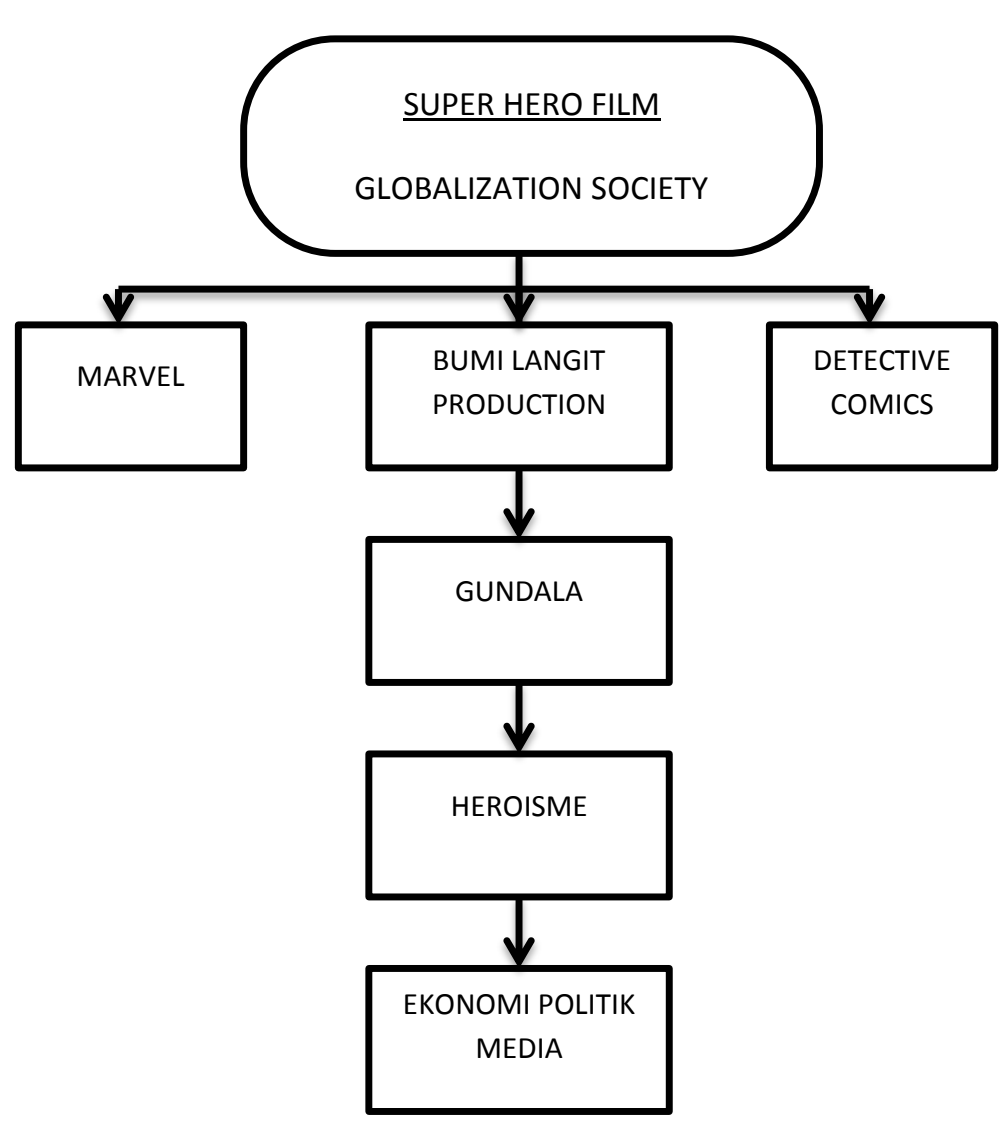

2.2.Road Map Penelitian

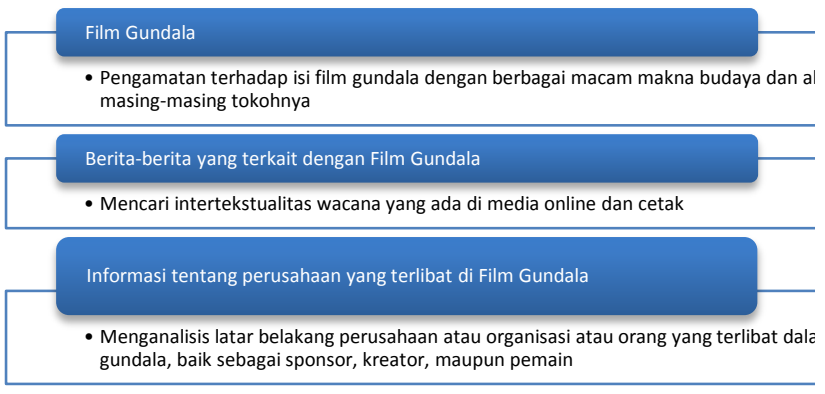

2.3.Desain Penelitian

Penelitian ini merupakan penelitian kualitatif dengan pendekatan kritis yang diwakili dengan terminologi pendekatan Marxisme terdapat tiga kelompok pendekatan yakni pendekatan strukturalist, ekonomi-politik dan pendekatan kulturalis. Pendekatan ekonomi politik, terdapat berbagai varian antara lain ditunjukkan dengan pengelompokkan berikut: dekonstruksi, rekonstruksi dan strukturalis. Pengelompokan lainnya (Golding dan Murdock, 1991) adalah analisis teks, analisis relasional dan supremasi khalayak (S. Sarwoprasodjo-Agung, Jurnal
Komunikasi Pembangunan : Februari 2008, Vol. 06, No. 1).

Desain untuk penelitian ini berlandaskan pada studi kasus. Menurut Yin (2012), studi kasus merupakan pendekatan empiris untuk menjawab pertanyaan atas satu atau banyak kasus. Selain itu, Yin (2012) juga menambahkan bahwa penting pula menentukan kasus yang akan diteliti. Beberapa karakteristik mendasar yang harus ada dalam sebuah kejadian agar dapat dikategorikan sebagai kasus, antara lain adalah kejadian yang ekstrim, unik, dan peristiwa besar.

Dalam lingkup penelitian ini, peneliti hanya akan fokus pada produksi makna sebagai praktek kekuasaan di film Gundala. Kesuksesan film gundala dengan ditunjang pemberitaan-pemberitaan di media cetak dan on-line membuat film tersebut menjadi fenomenal di Indonesia.

\section{METODE PENELITIAN}

Prosedur dalam penelitian ini menggunakan kualitatif dengan pendekatan ekonomi politik media. Penelitian kualitatif adalah sebuah proses penelitian untuk memahami masalah sosial atau masalah manusia, berdasarkan pada penciptaan gambaran holistik lengkap yang dibentuk dengan kata-kata, melaporkan pandangan informan secara terperinci dan disusun dalam sebuah latar alamiah (Cresswell, 2002: 1). Menurut Fraenkel \& Wallen, (1990) penelitian kualitatif memusatkan perhatian pada proses yang berlangsung. peneliti terutama tertarik untuk memahami bagaimana suatu hal terjadi. semenatara itu 
menurut Lincoln \& Guba, penelitian kualitatif merupakan sebuah desain berkembang dalam hal hasilnya. pengertian dan interpretasi dinegosiasikan dengan sumber data manusia karena realitas subyeklah yang ingin dipahami peneliti (Cresswell, 2002:156).

Pendekatan Ekonomi Politik mempunyai ciri khas utama sebagai berikut (Mosco, 1996):

1. Bersifat historis, karena berusaha memahami perubahan sosial dan transformasi sejarah dalam kaitannya dengan momen-momen ekonomi, politik, budaya dan ideologi dari kehiduapan sosial dengan dinamika yang berakar dari konflik sosial ekonomi. Proses-proses historis yang penting bagi ekonomi politik budaya adalah pertumbuhan media, perluasan jangkauan korporasi, komodifikasi, perubahan peran negara dan intervensi pemerintahan.

2. Analisis totalitas sosial atu holistik. Hal ini berarti bahwa politik ekonomi membahas masalah-masalah dalam kaitan dengan disiplin ilmu lain (sosiologi, politik dan ekonomi dll). Oleh karena itu seluruh arena sosial merupakan bidang analisis politikekonomi. Dalam kaitan dengan Marxian, totalitas itu berarti memahami hubungan politik dan ekonomi, juga bidang sosial dan budaya yang lebih luas. Sebagai contoh mempelajari dampak dinamika ekonomi terhadap keragaman ekspresi budaya publik dan ketersediaannya bagi kelompok sosial tertentu.

3. Berorientasi pada moral. Artinya mengacu pada konsepsi nilai-nilai sosial dan konsepsi mengenai praktek-praktek sosial yang pantas. Masalah moral mendasar yang menjadi perhatiannya adalah mengenai keadilan, kesetaraan, dan barang publik (public good). Kajian ekonomi politik media tidaklah bersifat bebas nilai dalam arti kajiannya didasari oleh kepentingan memperjuangkan keadilan, kesamaan dan kepentingan umum.

4. Orientasi praksis, yakni kajian ekonomi politik media diarahkan pada suatu tindakan yang mempunyai implikasi praktis. Dengan demikian kajian ekonomi politik dibangun oleh teori dan praktek. Kajian ekonomi politik media dimaksudkan untuk kepentingan praktis yang tercermin dalam tindakan perjuangan kelas.

\subsection{Pengembangan Instrumen}

Goulding dan Murdock menambahkan karakteristik lainnya yakni kajian ekonomi politik media juga mempunyai perhatian terhadap keseimbangan antara usaha kapitalis dan intervensi publik. Tiga area dalam ekonomi politis komunikasi menurut Goulding dan Murdock (1998) adalah:

1. Hubungan antara produksi barangbarang budaya dengan pentingnya anggapan keterbatasan (tetapi tidak sepenuhnya menentukan) dampak dari produksi budaya terhadap konsumsi budaya.

2. Ekonomi politis dari teks yakni untuk menggambarkan bagaimana representasi berhubungan dengan ekonomi politis dari konsumsi budaya.

3. Ekonomi politis konsumsi budaya, untuk menggambarkan hubungan antara bendabenda dengan ketidaksamaan budaya 
dimana ekonomi politik khususnya dialamatkan.

Analisis ekonomi-politik menurut Goulding dan Murdock (1996) berkenaan dengan produksi makna sebagai praktek kekuasaan, analisis tekstual dan konsumsi media. Perkembangan ekonomi dan teknologi telah menggeser status masyarakat sebagai warga politik menjadi unit konsumsi dalam masyarakat korporasi. Pertanyaan penting dari ekonomi politis komunikasi adalah bagaimana perubahan-perubahan berbagai kekuatan termasuk di dalamnya praktek-praktek kekuasaan terhadap produksi dan distribusi budaya membatasi atau memperluas ruang publik. Dua issue kunci berkenaan dengan hal tersebut adalah

(1) pola pemilikan institusi dan akibatnya pada pola penguasaan terhadap aktivitas mereka.

(2) Karakteristik hubungan antara pengaturan oleh negara dan lembaga komunikasi.

\subsection{Teknik Analisis Data}

Hoskins dkk (2004), Hiebert dkk (1991), McQuaill (1992) dan Albarran (1996) mengemukakan 3 kerangka analisis yang dapat menjelaskan berbagai sisi kerja bisnis media. Ketiga kerangka tersebut sekaligus merupakan indikator yang cukup relevan untuk menilai karakteristik industri media karena menyajikan informasi pokok terkait dengan keunikan operasi bisnis media massa. Ketiga kerangka analisis yang dimaksud meliputi struktur ekonomi (structure), operasionalisasi perusahaan (conduct), dan kinerja perusahaan (performance).

Pendekatan SCP sendiri pertama kali diperkenalkan oleh Mason (1939) yang kemudian diaplikasikan oleh Bain (1951) melalui studi lintas disiplin (Wirth dan Bloch, 1995). Esensi pendekatan SCP terhadap analisis organisasi industri adalah adanya hipotesis yang menyatakan bahwa performance atau keberadaan pasar (atau industri) dipengaruhi oleh perilaku perusahaan dalam pasar, sedangkan perusahaan dipengaruhi pula oleh berbagai variabel yang membentuk struktur pasar (Wirth dan Bloch, 1995). Berikut akan dipaparkan masing-masing bagian:

a. Struktur (Structure) mengacu pada struktur pasar yang biasanya ditentukan oleh rasio konsentrasi pasar. Rasio konsentrasi pasar adalah perbandingan yang mengukur distribusi pangsa pasar dalam industri. Sebuah industri yang $70 \%$ pangsa pasarnya dikuasai oleh hanya 2 perusahaan dalam industri misalnya, dapat disebut memiliki struktur pasar yang sangat terkonsentrasi. Untuk menilai struktur pasar ini diperlukan sejumlah variabel, antara lain jumlah penjual dan pembeli, tingkat diferensiasi produk, kemampuan perusahaan (khususnya bagaimana perusahaan menciptakan pilihanpilihan produk bagi konsumen), kemampuan perusahaan dalam menembus pasar bebas, seperti memperoleh lisensi dari pemerintah, franchise, hak monopoli, hak paten, dan hambatan yang terkait dengan biaya.

b. Perilaku (Conduct). Menurut Ferguson dan Ferguson (1994), istilah conduct mengacu pada perilaku 
perusahaan terhadap pasar dalam menentukan harga (baik harga yang ditentukan secara independen ataupun berdasarkan kesepakatan), strategi produk dan iklan, serta riset dan inovasi (Wirth dan Bloch, 1995). Penekanan hal ini adalah bagaimana perusahaan menentukan pilihan media iklan dan menyusun anggaran belanja untuk riset/melakukan penelitian terhadap produk dalam masyarakat. Scherer dan Ross (1990: 4) mengidentifikasi dua variabel lain dalam conduct: investasi dalam fasilitas produksi (misalnya, bagaimana perusahaan menyusun anggaran) dan sesuai dengan aturan hukum (yaitu penggunaan sistem hukum untuk menentukan posisi perusahaan dalam pasar) (Wirth dan Bloch, 1995).

c. Kinerja (Performance). Terdapat beberapa kriteria yang dapat digunakan untuk menilai kinerja ekonomi industri media, antara lain: keuntungan perusahaan; alokasi dan efisiensi produksi (dalam hal ini bagaimana caranya agar perusahaan tidak mengeluarkan sumber daya dengan percuma, dan bagaimana perusahaan dapat menghasilkan produk yang tepat baik dalam kuantitas, dan kualitas untuk memenuhi kepuasan konsumen); dan distribusi pendapatan yang sesuai. Lebih jauh, variabel performance yang melengkapi pengambilan keputusan industri media mencakup bagaimana perusahaan dalam pasar media memberikan kontribusi terhadap kesempatan yang sama bagi para pegawainya. Untuk keperluan analisis, variabel-variabel tersebut dapat disederhakan menjadi 3 indikator: (1) efisiensi, (2) penggunaan teknologi, dan (3) kemampuan meningkatkan akses audiens (pembaca/penonton/pengakses) (Ahmad Nashrudin Priatna, Jurnal Komunikasi dan Teknologi Informasi :Volume 9, No 1, Maret 2017).

\section{HASIL DAN PEMBAHASAN}

Kontektualisasi antara teori, objek penelitian dan metodologi penelitan akan menghasilkan pembahasan yang cukup menarik untuk ditelaah. Sebelum mengkorelaiskan semua elemen penelitian diatas, lebih baiknya membahas keunikan dan keberhasilan film gundala dilihat dari perspektif sutradara, aktor film, konsep film dan produser film gundala.

Film gundala yang disutradarai oleh Joko Anwar telah menjadi fenomana di Indonesia, karena merupakan film pertama yang bertemakan heroisme di Indonesia. Film tersebut mampu mengikuti deretan festival film di luar negeri, seperti; festival film toronto 2019 di Kanada, dan Paris International Fantastic Film Festival (PIFFF) 2019 di Perancis.

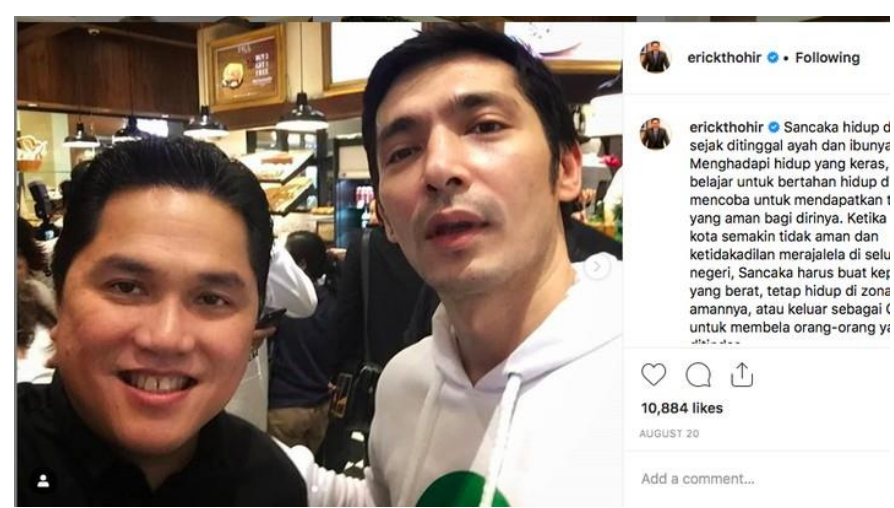

Gambar 4.1

Erick Tohir dan Abimana Arisatya sumber : cnbc indonesia .com

Selain didukung induk usaha EMTEK Grup, Bumilangit juga disokong oleh dua investor papan atas yakni Erick 
Thohir, bos Mahaka Media, dan emiten media PT Visi Media Asia Tbk (VIVA) milik keluarga Bakrie (sumber : www.cnbcindonesia.com).

Kesuksesan film gundala tidak terlepas dari intervensi Erick Thohir sebagai pemilik media massa yang cukup banyak dikuasainya. Dari data yang telah dihimpun melalui sumber media online lifepal.co.id bahwa Erick Thohir membawahi PT. Avabindo Perkasa (Mahaka Advertising), PT. Republika Media Mandiri (Harian Republika dan Republika Online), PT. Danapati Abinaya Investama (Jak TV), PT. Kalyanamitra Adhara Mahardhika (Alive! Indonesia), PT. Media Golfindo (Golf Digest Indonesia), dan PT. Mahaka Radio Integra, Tbk. (Gen FM dan Jak FM).

Pendekatan ekonomi politk media diawali dari analisis historis yang ada di subjek dan objek penelitian. Objek penelitian dalam riset ini adalah film gundala yang merupakan hasil karya komikus handal di era 1970 yaitu Harya Suraminata yang dikenal dengan nama Hasmi. Komik Gundala lahir karena pada tahun 1970 an masih belum ada sosok pahlawan kartun yang dipunyai oleh bangsa Indonesia. Dari situlah ide superhero Indonesia muncul untuk mengawali imajinasi pahlawan masyarakat indonesia. Hasmi yang lahir di Yogyakarta sangat erat sekali dengan budaya kejawen atau budaya Jawa yang sangat menjunjung tinggi falsafah "nguri-uri kabudayaan" yaitu menjaga, melestarikan dan mewariskan budaya ke generasi mendatang agar tidak hilang karena tergerus arus globalisasi dan modernisasi.

Hasmi menciptakaan karakter Gundala karena terinspirasi dari Ki Ageng Selo yang dapat menangkap petir. Menurut sumber Historia.id menjelaskan bahwa $\mathrm{Ki}$ Ageng Selo adalah orang Jawa (kerajaan demak waktu itu) yang mempunyai keturunan Brawijaya (raja terakhir majapahit). Prabu Brawijaya, dari istrinya yang paling muda yang berasal dari Wandan atau Bandan atau Pulau Banda Neira, mempunyai anak bernama Bondan Kejawen. Ki Ageng Selo merupakan cucu dari Bondan Kejawen.

Ki Ageng Selo hidup di masa Kerajaan Demak. Tepatnya pada masa kekuasaan Sultan Trenggana, awal abad ke16. Dia lahir sekitar akhir abad 15 atau awal abad 16. Ki Ageng Selo pernah ditolak menjadi anggota Prajurit Tamtama Pasukan Penggempur Kerajaan Demak.

Nama Ki Ageng Selo diambil dari salah satu desa di daerah Jawa tengah, tepatnya di kabupaten Grobogan desa Selo (sebelah timur Tawangharjo). Artinya bahwa inspirasi gundala oleh komikus Hasmi original dari Indonesia dengan mengangkat budaya Jawa. Faktor ekonomi pada masa tahun 1970 an yang akhirnya hanya sampai pada komik saja, tanpa bisa di film kan. Narasi dalam komik gundala edisi Hasmi di filmkan di era milenial oleh sutradara Joko Anwar. Ada beebrapa instrument yang akhirnya diganti oleh Joko Anwar, seperti kostum Gundala, pakaian yang dipakai sancaka, dan background dari film gundala itu sendiri. 
Pakaian Sancaka yang digambar oleh hasmi lebihdominan memakai warna hitam dan merah yang merupakan warna politik pada masa itu (sumber : $\mathrm{CNN}$ ). Partai yang dominan warna merah dan hitam pada tahun 1970 an adalah Partai Demokrasi Indonesia yang dapat dilihat dalam gambar dibawah ini :
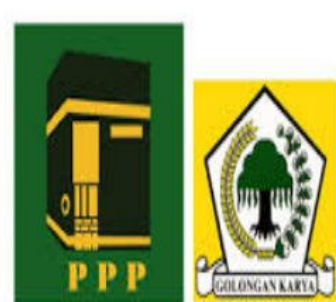

Gambar 4.2

Partai pemilu tahun 1970 an Sumber : donisetyawan.com

Partai yang ikut pemilu pada waktu itu hanya 3 partai; Partai Persatuan dan Pembangunan, Partai Golongan Karya, dan Partai Demokrasi Indonesia. Pada masa orde baru dibawha pimpinan presiden Soeharto memang partai tidak terlalu banyak pada tahun 2019 yang berjumlah 14 partai politik. Ketiga partai politik di era tahun 1970 an ada satu partai yang mengalami perubahan simbol dan bentuk, yaitu partai demokrasi Indonesia yang berubah menjadi partai demokrasi Indonesia perjuangan.

Kepemilikan partai demokrasi Indonesia diinisiasi oleh presiden pertama Ir. Soekarno, kemudian dipengang oleh Megawati Soekarno Putri yang merupakan presiden kelima republik Indonesia dan sekaligus berubah namanya menjadi PDI Perjuangan.

Pada pemilihan presiden tahun 2019 yang diikuti oleh 14 partai dan PDI Perjuangan memberikan suaranya ke Ir. H.
Joko Widodo atau biasa dikenal dengan Jokowi. Strategi pemilihan Presiden tahun 2019, Jokowi memutuskan untuk memberikan kepercayaan terhadap Erick Thohir sebagai Tim Kampanye Nasional.

Relasi kuasa antara Jokowi dengan Erick Thohir berlangsung tidak hanya di TKN saja, namun juga berlanjut dalam kontestasi pemilihan menteri setelah Jokowi memenangkan pilpres tahun 2019. Korelasi Erick thohir dengan film gundala sebagai investor bersama dengan group Bakrie.

Mahaka Media dan emiten media PT Visi Media Asia Tbk (VIVA) mensupport publikasi dan pemasaran film gundala. Berbagai macam lini media (online atau offline) diberitakan agar film gundala menjadi trending topik di Indonesia. Keluarga Bakrie yang mempunyai background politik partai Golkar merupakan partai koalisi dari PDI Perjuangan yang mengusung Jokowi sebagai Presiden RI.

Dari pernyataan diatas yang dihubungkan dengan analisis kedua dari ekonomi politik media, yaitu analisis totalitas sosial atau holistik menjadi sebuah analisis lintas keilmuan, yaitu politik, ekonomi dan sosial. Rating dan popularitas film Gundala akan berbanding lurus terhadap popularitas dan elektabilitas nama Erick Thohir dan Bakrie. Realita sosial tentang Gundala yang dinayatkan oleh Erick Thohir dan Bakrie lewat stasiun televisi atau media inoformasi miliknya menjadi kebenaran absolut. Hal ini sama dengan apa yang dikatakan Foucault (Bertens, 2001) tentang kuasa tidak bekerja secara negatif dan represif, melainkan dengan cara positif 
dan produktif. Kuasa mereprodusir realitas, mereprodusir lingkup-lingkup objek-objek, dan ritus-ritus kebenaran.

Film gundala yang berhasil memikat hati penonton masyarakat Indonesia hingga 1.38 juta penonton dan berhasil menempatkan posisinya di urutan ke enam film layar lebar terlaris di tahun 2019 (tirto.id). Aspek ekonomi yang menguntungkan bagi production house yang menjadi pembuat film gundala. Hal ini senada dengan yang diucapkan oleh Joko anwar sekaligus Sutradara Gundala saat diwawancarai oleh salah satu media online di Indonesia yaitu bisnis.com :

Ditemui di kesempatan yang berbeda saat rilis trailer film Perempuan Tanah Jahanam yang akan rilis Oktober mendatang, Joko Anwar sendiri mengakui film Gundala sudah untung.

"Sudah untung. Pokoknya sudah untung!" seru Joko Anwar.

Saat film Gundala menduduki peringkat keenam dengan kategori jumlah penonton terbanyak selama tahun 2019, secara tidak langsung crew film, sutradara, produser dan investor di film gundala sudah memperoleh keuntungan dan modal yang dikeluarkan telah kembali. Dari sudut ekonomi, maka laba sudah didapat setelah produk diperdagangkan di masyarakat. Keuntungan ekonomi yang diraih oleh Film Gundala tidak terlepas dari publikasi,eksistensi, dan aktualisasi crew film di media sosial dan konvensional. Menurut Teguh H. Rachmad (2016: 180) salah satu contoh eksistensi manusia di era postmodernisme adalah membuat subyek itu ada di media sosial dengan berbagai cara yang dilakukan, baik melalui tulisan, gambar dan video.

Analisis ketiga dalam pendekatan ekonomi politik media berkaitan dengan moral. Kajian ekonomi politik media tidaklah bersifat bebas nilai dalam arti kajiannya didasari oleh kepentingan memperjuangkan keadilan, kesamaan dan kepentingan umum. Film Gundala merupakan perjuangan bangsa Indonesia dari dunia ketiga untuk bisa setara dengan Negara Ameriak Serikat yang disebut sebagai Negara dunia Pertama.

Kehadiran sosok Hero Gundala di Indonesia membuktikan bahwa Negara dunia ketiga juga mempunyai hero yang sama dengan dunia pertama, seperti Captain Amerika, Iron Man, Spiderman, Captain Marvel, Hulk, dan masih banyak sosok hero yang lainnya. Kehadiran hero dunia pertama membuat imajinasi anak-anak dan orang dewasa di seluruh dunia menjadi referensi utama yang representative sebagai hero imajinasi yang mewakili Negara-negara di muka bumi ini. Indonesia mempunyai Gundala sebagai hero pertama yang ditayangkan di layar lebar atau bioskop sebagai perwakilan Negara inferior yang mampu bersaing dengan Negara superior seperti amerika, inggris dan beberapa Negara di benua eropa.

Analisis keempat yang merupakan langkah analisis terakhir dari pedekatan ekonomi politik media adalah orientasi praksis. Film gundala yang disutradarai oleh Joko Anwar (sutradara kondang yang mampu mengorbitkan artis-artis dan film yang dilakoninya) bergenre heroisme 
mempunyai ideologi nasionalisme. Ideologi adalah tipe wacana yang membenarkan legitimasi dengan mengacu pada realisme transcendental, realisme tuhan-tuhan, figure spiritual dan mitis (Thompson: 2014). Di Negara Indonesia, masyarakat akan menonton film gundala karena mau melihat legitimasi hero asli Indonesia yang merupakan representasi figure imajinasi hero di Indonesia.

Semua orang akan menonton gundala, khususnya masayarakat Indonesia dikarenakan hero asli bangsa Indonesia bukan dari bangsa barat. Peluncuran perdana film gundala di bulan agustus 2019 merupakan representasi rasa nasonalisme rakyat Indonesia terhadap hari kemerdekaan republic Indonesia. Moment yang tepat sekali tidak disia-siakan oleh bumi langit production untuk menarik animo masyarakat agar film gundala menjadi viral dan banyak ditonton oleh masyarakat Indonesia dari seluruh Negara di penjuru dunia.

Strategi penayangan film perdana di hari kemerdekaan tersebut berhasil dengan indikator banyak prestasi yang didapat dari film gundala. Kehadiran Erick Thohir dan Bakrie memperkuat strategi ideologi heroisme di film gundala, dikarenakan relasi kuasa yang dekat dengan Partai PDI Perjuangan yang merupakan partai koalisi dari Golkar.

\section{PENUTUP}

Film gundala yang bergenre heroisme adalah sosok hero pertama kali di Indonesia yang merupakan bentuk perjuangan kelas sebagai negara dunia ketiga untuk dapat sejajar dengan negara adikuasa seperti negara amerika serikat yang memperoduksi film super hero dan terkenal di seluruh dunia yaitu Marvel dan DC.

Dibalik wacana film gundala terdapat ideologi nasionalisme yang bekaitan erat dnegan hero asli indonesia yang dibuat oleh komikus asli jawa tengah dan menyukai partai PDI sama dengan presiden jokowi.

Penayangan perdana film gundala di bulan agustus 2019 adalah strategi pengambilan konsumen yang cukup tepat sekali. Dibalik ketepatan momentum di bulan agustus untuk memperkuat rasa nasionalisme, banyak sekali keuntungan baik materi maupun non materi yang didapat oleh orang-orang yang bekerja dibelakang layar Gundala.

\section{DAFTAR PUSTAKA}

Bertens, K. 2001. Filsafat Barat Kontemporer Prancis. Jakarta: Gramedia.

Cresswell, John W. 2002. Research Design: Qualitative and Quantitative Approaches. KIK Press. Jakarta

Golding and Murdock. (1991). "Culture Communication, and Political Economy" dalam Curran dan Gurevitch

McQuail, D., J. Blumler \& R. Brown (1972): 'The television audience: a revised perspective' in D. McQuail (ed.): Sociology of Mass Communication. London: Longman 
Mosco, Vincent. (1996). The Political Economy of Communication. Sage Publications. London, Thousanbd Oaks, New Delhi.

Rachmad, Teguh H. 2016. Kontestasi New Media dalam buku Media Lokal: Kontestasi, Trend, Dinamika dan Suara Media Arus Bawah Madura. Elmatera: Yogyakarta

Robert K. Yin, 2012. Studi Kasus Desain \& Metode, Raja Grafindo Jakarta.

Thompson, John B. Analisis Ideologi Dunia Kritik Wacana Ideologi Ideologi Dunia. IRCiSoD : Jogjakarta

Jurnal :

http://journals.ums.ac.id/index.php/komuniti /article/view/3962

https://jurnal.ipb.ac.id/index.php/jurnalkmp/ search/authors/view?givenName=S.\%20 Sarwoprasodjo\&familyName=Agung\&a ffiliation $=\&$ country $=$ ID \&authorName $=$ Agung\%2C\%20S.\%20Sarwoprasodjo

Internet :

https://www.nielsen.com/id/en/press-

releases/2019/konsumen-indonesiatetap-optimistis-di-akhir-tahun-2018/ https://seleb.tempo.co/read/1244979/erick-

thohir-film-gundala-bukan-balik-modal-

$\underline{\text { sudah-untung/full\&view=ok }}$

https://www.cnbcindonesia.com/market/ 20190901110038-17-96324/kenapaerick-thohir-bakrie-masuk-di-gundala

https://lifepal.co.id/media/perusahaan-erickthohir/

https://www.cnnindonesia.com/hiburan/201 90829184102-234-425873/cerita-

kelahiran-gundala-dan-hasrat-

superhero-rasa-lokal

https://historia.id/kultur/articles/ki-ageng-

selo-sang-penangkap-petir-

$\underline{6 \mathrm{~m} 7 \mathrm{wx} / \mathrm{page} / 1}$

http://www.donisetyawan.com/fusi-partai-

di-indonesia-tahun-1973/

https://tirto.id/jumlah-penonton-gundalacapai-13-juta-salip-bumi-manusiamakmum-ehTL

https://lifestyle.bisnis.com/read/20190918/2 $\underline{54 / 1149834 / \text { sudah-untung-tapi- }}$ mengapa-kenaikan-jumlah-penontongundala-lambat 